\title{
Genetic identification and characterization of Armenian grapevine cultivars
}

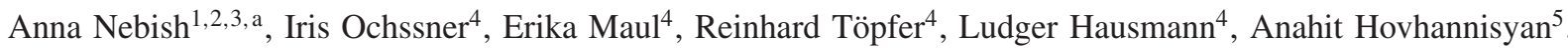 \\ Hakob Devejyan ${ }^{2}$, Gagik Melyan ${ }^{3}$, and Rouben Aroutiounian ${ }^{1,2}$ \\ ${ }^{1}$ Department of Genetics and Cytology, Yerevan State University, 1 Alex Manoogian, 0025 Yerevan, Armenia \\ ${ }^{2}$ Research group of Plant genetics and Immunology, Institute of Molecular Biology of National Academy of Sciences RA, \\ 7 Hasratyan, 0014 Yerevan, Armenia \\ ${ }^{3}$ Scientific Center of Viticulture, Fruit-Growing and Wine-Making of the Armenian National Agrarian University, \\ 1139 Merdzavan, Armenia \\ ${ }^{4}$ Institute for Grapevine Breeding, Julius Kühn-Institut (JKI), Geilweilerhof, 76833 Siebeldingen, Germany \\ ${ }^{5}$ Laboratory of Ethnogenomics, Institute of Molecular Biology of National Academy of Sciences RA, 7 Hasratyan, 0014 \\ Yerevan, Armenia
}

\begin{abstract}
Armenia is an important area of crop origins including grapes. The objectives of this study were the molecular characterization of 38 Armenian grape genotypes and the detection of the genetic relationships between the accessions. In total, 164 alleles were obtained at 18 SSRs loci. The number of alleles per locus ranged from 5 to 15 with a mean number of 9.17 alleles per locus. The expected heterozygosity ranged from 0.514 (VVIN73) to 0.90 (VVS2) and the observed heterozygosity from 0.417 (VVIV37) to 0.947 (VVMD7 and VMC1B11). In our research the highest values of polymorphic information content (PIC) were obtained using markers VVS2, VRZAG62 and VRZAG79, while the least informative ones were VVIN73 and VVIB01. A high level of gene diversity was observed between ancient and new bred cultivars. Higher values were recorded for the new grape varieties, $(\mathrm{He}=0.792)$ and lower values for ancient cultivars $(\mathrm{He}=0.739)$. The mean number of alleles (MNA) for all loci per population ranged from 7.39 in ancient to 8,00 in new crosses. A clear separation was observed for the groups of ancient aboriginal cultivars, Vitis vinifera L. xVitis vinifera L. and Vitis vinifera L. x Vitis amurensis Rupr .crosses, which were bred in Armenia and seedless cultivars. Very close relationships with high similarity were determined for 5 pairs of cultivars. Two cases of possible homonymy were also detected. Our results are the basis for future MAS selection and target breeding.
\end{abstract}

\section{Introduction}

Armenia has a long history of viticulture and winemaking. Numerous wild grapevine (Vitis vinifera L. subsp. sylvestris) populations are thriving in the country and a rich biodiversity of local grapevine genetic resources including more than 450 traditional autochthonous cultivars exist [1]. The earliest traces of grape domestication and cultivation were found in the Armenian highlands dating to the ancient Neolithic settlements (6,000-5,000 BC) [2-4]. The oldest evidence of wine-production (Areni-1 cave) was found in southeastern Armenia dating to 4,000 $\mathrm{BC}$ [5]. Armenia is a mountainous country with a dry and continental climate with hot summers and cold winters. Climatic conditions are favorable for the successful cultivation of grapes for different usage, e.g., differing in ripening time and yield. However, very low temperatures in winter as low as $-35^{\circ} \mathrm{C}$ can sometimes cause great damage to the grape plants. Thus the winter frost tolerant species Vitis amurensis Rupr. was widely used in breeding programs at the Armenian Scientific Research Institute of Viticulture, Fruit-Growing and Winemaking.

a e-mail: anita.nebish@gmail.com
Nowadays, two ampelographic field collections are present in Armenia:

1. The collection of the Scientific Center for Viticulture, Fruit Growing and Wine-Making (Nalbandyan, Armavir province);

2. The new ampelographic collection at the Scientific Center of Agriculture (Echmiadzin, Armavir province) established in 2016.

The classification of Armenian grapevine cultivars is traditionally based on classical ampelographic characteristics according to OIV descriptors. However, the common morphological identification has different limitations and does sometimes not provide enough evidence for the correct identification of the accessions [6].

Having already been studied by the methods of ampelography, Armenian grapevine biodiversity still needs to be investigated on a molecular level in accordance with modern requirements. During the last few years, eighty Armenian cultivars have already been identified and characterized according to OIV phenotypic descriptors $[7,8]$, but their genotypic characteristics are yet to be identified. The genetic analysis of Armenian grapevine cultivars is essential for the correct description of 
genetic resources and the ascertainment of genetic relationships between grapevine genotypes and their pedigrees.

DNA microsatellite markers, or simple sequence repeats (SSRs), are widely used in the molecular characterization of grapevine germplasm and cultivar identification. Due to their high degree of polymorphism, co-dominance and stability they are used as a complementary tool to traditional ampelographic methods, as well as for the evaluation of genetic diversity and clarification of nomenclature [9-12]. SSR markers are thus in use for DNA fingerprinting and also for molecular marker-assisted selection (MAS) in breeding programs $[13,14]$ as well as for studying the historical origin of grape [15].

The objectives of this study were the molecular identification of Armenian grape genotypes including ancient as well as new cultivars using SSR analysis and the detection of the genetic relationships between the investigated accessions.

\section{Material and methods}

Plant material. Thirty-eight accessions were chosen from (1) the Armenian National Grape collection (WIEWS-Institute code: ARM011, Armenian Academy of Viticulture and Winemaking, Nalbandyan, Armenia; 31 genotypes) and (2) the German national grape collection (WIEWS-Institute code DEU098, Julius KühnInstitut, Institute for Grapevine Breeding Geilweilerhof, JKI-IRZ; 7 genotypes). The material included 19 ancient Armenian and 10 newly bred $V$. vinifera $L$. cultivars as well as 9 interspecific crosses (V.vinifera. x V.amurensis). Table 1 lists the analyzed cultivars, the institute code of the grapevine collection, the species and the pedigree given by the breeder. In our study 'Karmrahyut' (V.vinifera $\mathrm{x}$ V.amurensis interspecific cross) is the parental genotype of the cultivars 'Charentsi', 'Nalbandyani', 'Agaraki', 'Anushahyut', 'Nerkarat' and possibly 'Csarensi'. The two $V$. vinifera cultivars 'Cabernet franc' and 'Muscat à petits grains blancs' were used as references for the standardization of allele sizes and for the comparison of genetic profiles with microsatellite databases.

DNA isolation and microsatellite genotyping. Samples of 8-10 young leaves per genotype were collected and dried in silica gel from the ARM011 collection. Samples from the DEU098 collection were collected and stored at $-20^{\circ} \mathrm{C}$ until extraction of genomic DNA. DNA was extracted from all leaves using the DNeasy Plant Maxi Kit (Qiagen) following the manufacturer's instructions. DNA concentration and purity was estimated using the Thermo Scientific NanoDrop 2000 spectrophotometer. For the genetic characterization of the Armenian cultivars the collected material was genotyped in multiplexes at the following 18 microsatellite loci: VVS2 [16], VVMD5, VVMD7, VVMD24, VVMD25, VVMD32 [17, 18], VRZAG62, VRZAG79 [19], VVIB01, VVIH54, VVIN16, VVIN73, VVIP31, VVIP60, VVIV37, VVIV67 [20], VMC1B11 [21] and VMC4f3.1 [22]. The majority of these SSR markers is commonly used for the assessment of trueness to type in grapevine collections and the search of putative relationships. (European project GENRES081, http: //www.genres .de/vitis) [23-26].

One primer of each marker was fluorescently labeled at the $5^{\prime}$ end with FAM (blue), TAMRA (yellow), HEX (green), ROX or NED (red) (Metabion, Martinsried, Germany). Up to 6 markers with different labels and diverse fragment lengths were combined in multiplexes and polymerase chain reaction (PCR) was performed using $5 \mu \mathrm{l}$ reaction mixtures containing master mix, $100 \mathrm{pmol} / \mu \mathrm{l}$ of each primer and $1 \mathrm{ng} / \mu \mathrm{l}$ of template DNA using a GeneAmp PCR system 9700 thermal cycler (Applied Biosystems, Darmstadt, Germany). Amplification was started with a $15 \mathrm{~min}$ initial denaturation at $95^{\circ} \mathrm{C}$, followed by 30 cycles with denaturation at $95^{\circ} \mathrm{C}$ for $30 \mathrm{~s}$, annealing at $60^{\circ} \mathrm{C}$ for $90 \mathrm{~s}$ and extension at $72^{\circ} \mathrm{C}$ for $60 \mathrm{~s}$. A final extension was performed at $72^{\circ} \mathrm{C}$ for $7 \mathrm{~min} .1 \mu \mathrm{l}$ of the PCR product was used for fragment length determination using an ABI $3130 \times l$ Genetic Analyzer (Applied Biosystems, Foster City, USA) at the Institute for Grapevine Breeding Geilweilerhof at the Julius Kühn Institute (Siebeldingen, Germany). The results were processed with GeneMapper software version 4.0 (Applied Biosystems, Darmstadt, Germany).

Data analysis. The genotypic data obtained for the 38 Armenian grapevine accessions were processed using the genetic analysis software Cervus(c) 3.0.7 (Copyright Tristan Marshall 1998-2014) [27]. Homozygous genotypes show a single peak at the investigated locus. Cervus software was used to calculate allele frequency and number of alleles per locus, estimated frequency of null alleles and probability of identity per locus, expected and observed heterozygosity [28], probability of identity per locus and the polymorphic information content for diversity analysis. The Arlequin 3.5 software was used to calculate gene diversity and observed heterozygosity per population for two groups of cultivars: (1) ancient cultivars and (2) newly bred cultivars including those obtained by open pollination [29]. Genotypic results were converted to a similarity matrix and a dendrogram was constructed with the algorithm UPGMA (unweighted pair-group method with arithmetic mean) using the NTSYS-pc software (Numerical Taxonomy and Multivariate Analysis System, ver. 2.1) [30].

Results and discussion. The analysis of the genetic diversity of the Armenian grape accessions of different origin included the average number of alleles per locus $(\mathrm{Na}), R a$ - range of alleles sizes ( $b p)$, allele frequency, estimated heterozyosity ( $\mathrm{He}$ ) and observed heterozygosity (Ho), probability of identity (PI), frequency of null alleles (Fo) and polymorphic information content (PIC) (Table 2).

In our research a total of 164 alleles were obtained at the 18 SSRs loci analyzed. The number of alleles per locus ranged from 5 (VVIN16, VVIB01, VVIN73) to 15 (VVS2) with a mean number of 9.17 alleles per locus. According to other authors the average number of alleles per locus for grape accessions of different geographical origins ranged from 8.17 [31] to 24.4 [32].

The expected heterozygosity of the investigated cultivars ranged from 0.514 (VVIN73) to 0.90 (VVS2) with a mean 0.789 . This value is less than data obtained by Martinez et al. (2006) (0.810) and Martin et al. (2003) $(0.806)$ [33,34]. The lowest observed heterozygosity (0.417) was detected at the VVIV37 locus and the highest at the VVMD7 and VMC1B11 loci (0.947). The high heterozygosity at some of the loci may be explained by the high number of crosses in the cultivar set. Twenty from the 38 investigated cultivars are new, including $11 \mathrm{~V}$. vinifera 
Table 1. List of grape accessions evaluated in this study.

\begin{tabular}{|c|c|c|c|c|c|}
\hline ID & Cultivar name & Short name & Institute code & Species & Pedigree \\
\hline $\mathbf{1}$ & Areni & ARE & ARM011 & $V$. vinifera $L$. & Ancient \\
\hline 2 & Areni chernyi & $\mathrm{ACH}$ & DEU098 & V. vinifera $L$. & Ancient \\
\hline 3 & Ararati & ARA & ARM011 & $V$. vinifera $L$. & Ancient \\
\hline 4 & Arevar & ARV & ARM011 & V. vinifera $L$. & Ancient \\
\hline 5 & Chilar & CHL & ARM011 & $V$. vinifera $L$. & Ancient \\
\hline 6 & Garan dmak & GDM & ARM011 & $V$. vinifera $L$. & Ancient \\
\hline 7 & Eraskheni & ERA & ARM011 & V. vinifera $L$. & Ancient \\
\hline 8 & Itsaptuk & ITS & ARM011 & $V$. vinifera $L$. & Ancient \\
\hline 9 & Hastamashk & HMK & ARM011 & $V$. vinifera $L$. & Ancient \\
\hline 10 & Kakhet & KKH & ARM011 & $V$. vinifera $L$. & Ancient \\
\hline 11 & Marmari & MAR & ARM011 & $V$. vinifera $L$. & Ancient \\
\hline 12 & Mskhali & MSK & ARM011 & V. vinifera $L$. & Ancient \\
\hline 13 & Mskhali clone & MSC & ARM011 & $V$. vinifera $L$. & Ancient \\
\hline 14 & Parvana & PAR & ARM011 & $V$. vinifera $L$. & Ancient \\
\hline 15 & Spitak Arakseni & SPA & ARM011 & $V$. vinifera $L$. & Ancient \\
\hline 16 & Spitak kaqavik & SPK & ARM011 & V. vinifera $L$. & Ancient \\
\hline 17 & Vanqapatkan & VQP & ARM011 & $V$. vinifera $L$. & Ancient \\
\hline 18 & Voskehat & VOS & ARM011 & $V$. vinifera $L$. & Ancient \\
\hline 19 & Armenia & ARM & ARM011 & $V$. vinifera $L$. & $\begin{array}{l}\text { Itsaptuk (synonymKhusaine Belyi)X } \\
\text { Sateni Chernyi }\end{array}$ \\
\hline 20 & Shahumyani & SHA & ARM011 & V. vinifera $L$. & $\begin{array}{l}\text { Itsaptuk (synonymKhusaine Belyi), } \\
\text { Open pollination }\end{array}$ \\
\hline 21 & Anush & ANU & ARM011 & V. vinifera $L$. & $\begin{array}{l}\text { Armenia (Khusaine Belyi X Sateni } \\
\text { Chernyi) X KishmishRozovyi }\end{array}$ \\
\hline 22 & Karmir kakhani & KAH & DEU098 & $V$. vinifera $L$. & Tana Kouzy XSevan \\
\hline 23 & Muscat Tskha & MTS & ARM011 & V. vinifera $L$. & $\begin{array}{c}\text { Madeleine Angevine X Muskat } \\
\text { Desertnyi }\end{array}$ \\
\hline 24 & Muscat haykakan & MHA & ARM011 & V. vinifera $L$. & $\begin{array}{l}\text { Muskat Chernyi (free pollination) x } \\
\text { Muscat a Petits Grains Noirs }\end{array}$ \\
\hline 25 & Muscat Yerevani & MUY & ARM011 & $V$. vinifera $L$. & C 484 X Rizamat \\
\hline 26 & Merdzavani vaghahas & MEV & ARM011 & $V$. vinifera $L$. & $\begin{array}{c}\text { C } 484 \text { (Madeleine Angevine X Chasselas } \\
\text { Musque) X Kishmish Khishrau (Nimrang } \\
\text { X Kishmish Noir) }\end{array}$ \\
\hline 27 & Nazeli & NAZ & ARM011 & V. vinifera $L$. & Sultanine XBlanc D'iran \\
\hline 28 & Tokun & TOK & ARM011 & $V$ vinifera $L$. & Spitak Arakseni, open pollination \\
\hline 29 & Agaraki & AGA & DEU098 & $\begin{array}{l}\text { V. vinifera L.x } \\
\text { V. amurensis Rupr. }\end{array}$ & $\begin{array}{c}\text { V. vinifera L. }(\mathrm{NO} .1563 / 1+21) \mathbf{X} \\
\text { Karmrahyut }\end{array}$ \\
\hline 30 & Anushahyut & ANH & DEU098 & $\begin{array}{l}\text { V. vinifera L.x } \\
\text { V.amurensis Rupr. }\end{array}$ & $\begin{array}{c}\text { C } 1262 \text { (V. amurensis Rupr. X Perle Von) } \\
\text { Csaba) X Karmrahyut }\end{array}$ \\
\hline 31 & Burmunk & BUR & ARM011 & $\begin{array}{l}\text { V. vinifera L.x } \\
\text { V.amurensis Rupr. }\end{array}$ & $\begin{array}{c}\text { V.amurensis Rupr. X Muscat Fleur } \\
\text { D'Oranger }\end{array}$ \\
\hline 32 & Charentsi & CHA & ARM011 & $\begin{array}{l}\text { V. vinifera L.x V.amurensis Rupr. } \\
\text { V.amurensis Rupr. }\end{array}$ & $\begin{array}{l}\text { Seyanets C } 1262 \text { (V.amurensis Rupr. X } \\
\text { Zhemchug Saba) X Karmrahyut }\end{array}$ \\
\hline 33 & Csarenci & CSA & DEU098 & $\begin{array}{c}\text { V. vinifera L.x } \\
\text { V.amurensis Rupr. }\end{array}$ & V. vinifera L.x V.amurensis Rupr. \\
\hline 34 & Karin & KAR & DEU098 & $\begin{array}{l}\text { V. vinifera L.x } \\
\text { V.amurensis Rupr. }\end{array}$ & $\begin{array}{c}\text { Lernatu X Fioletovyi Rannii } \\
\text { V.amurensis Rupr xV. vinifera L..) }\end{array}$ \\
\hline 35 & Nalbandyani & NAB & ARM011 & $\begin{array}{l}\text { V. vinifera L.x } \\
\text { V.amurensis } R \text { Rupr. }\end{array}$ & Karmrahyut X Seyanets $1563 / 1+21$ \\
\hline 36 & Nerkarat & NRA & DEU098 & $\begin{array}{l}\text { V. vinifera L.x } \\
\text { V.amurensis } R \text { Rupr. }\end{array}$ & $\begin{array}{c}\text { C } 1262 \text { (V.amurensis Rupr. X Perle Von } \\
\text { X Csaba) X Karmrahyut }\end{array}$ \\
\hline 37 & Nerkeni & NER & ARM011 & $\begin{array}{l}\text { V. vinifera L.x } \\
\text { V.amurensis Rupr. }\end{array}$ & $\begin{array}{c}\text { Saperavi X("Garan Dmak X) } \\
\text { Kikhet) }\end{array}$ \\
\hline 38 & Karmrahyut & KRH & ARM011 & $\begin{array}{l}\text { V. vinifera L.x } \\
\text { V. V.amurensis Rupr. }\end{array}$ & $\begin{array}{c}\text { Hadisi X No 15-7-1 (V.amurensis Rupr. X } \\
\text { X Sladkii Chernyi) }\end{array}$ \\
\hline
\end{tabular}

and $9 V$. vinifera $\times$. amurensis crosses. The probability of identity (PI) values for different loci ranged from 0.023 (VVS2) to 0.291 (VVIN73).

Polymorphic information content (PIC) for each locus was calculated for the evaluation of the effectiveness of each marker (Table 2). In our research PIC values were lower than the values of expected heterozygosity and higher than 0.7 for the majority of loci meaning that these loci are highly informative. The most informative loci were VVS2 (0.899), VRZAG62 (0.862) and VRZAG79 (0.857), while the least informative were the VVIN73 and VVIB01 loci with a PIC value of 0.459 and 0.575 , 
Table 2. Genetic parameters for SSR loci in Armenian accessions.

\begin{tabular}{lccccccc}
\hline Locus & Na & Ra & He & Ho & PI & Fo & PIC \\
VVMD5 & 8 & $226-248$ & 0.825 & 0.730 & 0.059 & 0.060 & 0.789 \\
VVMD7 & 9 & $233-255$ & 0.817 & 0.947 & 0.064 & -0.087 & 0.780 \\
VVMD24 & 7 & $206-219$ & 0.809 & 0.868 & 0.069 & -0.046 & 0.770 \\
VVMD25 & 7 & $235-255$ & 0.737 & 0.658 & 0.120 & 0.045 & 0.682 \\
VVMD32 & 12 & $240-277$ & 0.773 & 0.667 & 0.083 & 0.047 & 0.736 \\
VVIV37 & 9 & $152-182$ & 0.799 & 0.417 & 0.073 & 0.310 & 0.760 \\
VVIV67 & 11 & $352-383$ & 0.809 & 0.611 & 0.061 & 0.143 & 0.777 \\
VVIN16 & 5 & $147-157$ & 0.671 & 0.763 & 0.166 & -0.076 & 0.628 \\
VVIN73 & 5 & $260-272$ & 0.514 & 0.595 & 0.291 & -0.099 & 0.459 \\
VVIH54 & 10 & $139-177$ & 0.856 & 0.632 & 0.042 & 0.142 & 0.828 \\
VVIB01 & 5 & $294-312$ & 0.653 & 0.763 & 0.196 & -0.100 & 0.575 \\
VVIP31 & 11 & $173-196$ & 0.847 & 0.895 & 0.045 & -0.034 & 0.818 \\
VVIP60 & 9 & $306-332$ & 0.755 & 0.789 & 0.100 & -0.041 & 0.710 \\
VMC1B11 & 8 & $168-191$ & 0.809 & 0.947 & 0.068 & -0.090 & 0.771 \\
VMC4f3.1 & 12 & $165-208$ & 0.874 & 0.868 & 0.032 & -0.009 & 0.848 \\
VVS2 & 15 & $124-161$ & 0.901 & 0.871 & 0.023 & 0.021 & 0.876 \\
VRZAG62 & 10 & $184-204$ & 0.878 & 0.758 & 0.033 & 0.065 & 0.876 \\
VRZAG79 & 12 & $237-261$ & 0.881 & 0.676 & 0.030 & 0.130 & 0.856 \\
\hline Mean & 9.17 & - & 0.789 & 0.748 & 0.086 & 0.021 & 0.752 \\
\hline
\end{tabular}

Table 3. The most frequent alleles per locus and their frequency.

\begin{tabular}{|c|c|c|c|c|c|c|c|c|c|c|}
\hline SSR-marker & VVMD5 & VVMD7 & VVMD24 & VVMD25 & VVMD32 & VVIV37 & VVIV67 & VVIN16 & VVIN73 \\
\hline Most frequent allele & 238 & 239 & 208 & 241 & 272 & 154 & 360 & 151 & 268 \\
\hline Major allele frequency, \% & 27.03 & 28.95 & 28.95 & 38.16 & 40.28 & 34.72 & 37.50 & 48.68 & 66.22 \\
\hline \multicolumn{10}{|l|}{} \\
\hline SSR-marker & VVIH54 & VVIB01 & VVIP31 & VVIP60 & VMC1B11 & VMC4f3.1 & VVS2 & VRZAG62 & VRZAG79 \\
\hline Most frequent allele & 163 & 294 & 183 & 322 & 168 & 181 & 137 & 186 & 247 \\
\hline Major allele frequency, \% & 25.0 & 43.42 & 30.26 & 38.16 & 31.58 & 21.05 & 19.35 & 21.21 & 21.62 \\
\hline
\end{tabular}

Table 4. Genetic variability within the studied population: observed and expected heterozygosity (Ho and He), mean number of alleles (MNA), averaged over all loci.

\begin{tabular}{|c|c|c|c|}
\hline Population & $\mathbf{H}_{\mathbf{o}} \pm$ s.d. & $\mathbf{H}_{\mathbf{e}} \pm$ s.d. & MNA \\
\hline Ancient cultivars & $0.753 \pm 0.161$ & $0.779 \pm 0.082$ & 7.39 \\
\hline New crosses & $0.739 \pm 0.171$ & $0.792 \pm 0.118$ & 8.00 \\
\hline
\end{tabular}

respectively. According to literature data, VRZAG62 [33] and VRZAG79 [35] were the most informative ones both with PIC values of 0.88 which comes very close to our data.

The most frequent alleles at each locus and their frequencies are presented in Table 3. The highest frequency of alleles was registered for VVIN73 - 268 $(66.22 \%)$, VVIN16 - 151 (48.68\%), VVIB01 - 294 $(43.42 \%)$ and VVMD32 - $272(40.28 \%)$. In total, 68 rare alleles $(41,46 \%)$ for all loci were found with a frequency of occurrence of less than $5 \%$.

In Table 4 the genetic variability of ancient cultivars and the new bred $V$. vinifera $\mathrm{x} V$. vinifera and $V$. vinifera $\mathrm{x}$ $V$. amurensis varieties is presented. Observed and expected heterozygosity (Ho and $\mathrm{He}$ ) for all loci was high on average in both populations. The higher variation of gene diversities with (He) 0.792 was obtained for interspecific crosses and a lower value of 0.739 was found in the ancient cultivars. The mean number of alleles (MNA) for all loci per population ranged from 7.39 in ancient to 8.00 in new cultivars.

Genetic relatedness. The dendrogram shown in Fig. 1 was constructed using the UPGMA method for the evaluation of genetic diversity and relatedness between the investigated cultivars. In the dendrogram the investigated cultivars were separated into two main clusters. The smaller cluster included only the two cultivars 'Agaraki' and 'Karin' from the German collection. Both genotypes are interspecific crosses ( $V$. vinifera $\times$ V. amurensis). The ancient cultivar Eraskheni separates from the other two. The large cluster exhibited 4 distinct subclusters labelled S1, S2, S3 and S4 and the interspecific cross 'Burmunk' which is characterized by a very high sugar content in its berries (more than 30\%) and very high frost resistance.

Subcluster S1 was separated into two smaller subgroups, with the first one including only interspecific crosses ( $V$. vinifera $\mathrm{x} V$. amurensis) from both $\mathrm{Ar}$ menian and German collections: 'Anushahyut', 'Csarensi', 'Nerkarat', 'Charentsi' and 'Nerkeni'. The first four of them are offspring of 'Karmrahyut'. The second subgroup included three ancient cultivars - 'Areni', 'Areni chernyi' and 'Chilar'.

The second subcluster S2 separated into two distinct subgroups. The first one included mainly ancient cultivars and also 'Itsaptuk' (synonym 'Khusaine belyi'), its offspring 'Shahumyani' and 'Armenia' together with 


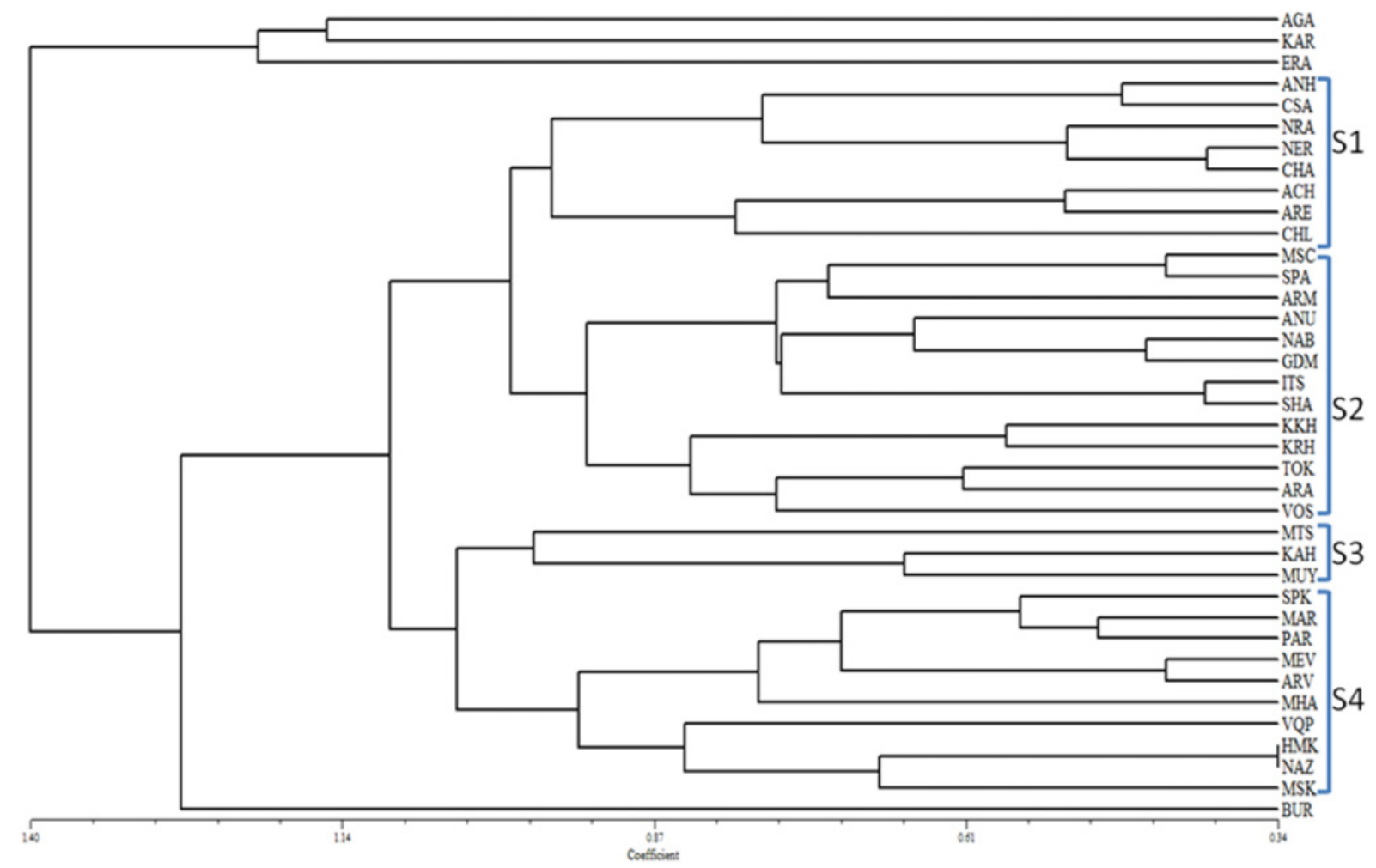

Figure 1. Genetic relationships in Armenian grapevine cultivars based on SSR analysis.

Armenia's offspring 'Anush'. In the second subgroup the ancient cultivar 'Kakhet' was grouped with 'Karmrahyut'. It seems that the name 'Karmrahyut' of this accession is incorrect because it did not group into cluster 1 or subcluster S1 which included its offspring and other $V$. vinifera $\mathrm{x} V$. amurensis. crosses, although we did not investigate the second parental genotypes of the crosses.

The second part of the subgroup was formed by the ancient cultivars 'Voskehat' and 'Ararati', and the cultivar 'Tokun' obtained as the result of open pollination of the ancient cultivar 'Spitak Arakseni'.

Subcluster S3 included three $V$. vinifera interspecific cultivars: 'Muscat Tskha', 'Muscat Yerevani' and 'Karmir kakhani'.

The fourth subcluster S4 was made up of ten accessions which were separated into two sub groups and included mainly ancient cultivars. 'Spitak kaqavik', 'Marmari' and 'Parvana' seedless fell into the first subgroup. Unexpectedly, the newly bred cultivar 'Nazeli' fell into the second subgroup together with the ancient cultivars 'Hastamashk', 'Vanqapatkan' and 'Maskhali'.

The closest relationships were detected between the following pairs of genotypes: The ancient cultivar 'Itsaptuk' and its offspring 'Sahumyani' obtained in the result of open pollination; 'Anushahyut' and 'Csarenci', both from the German collection, which are offsprings of the same parent 'Karmrahyut' ( $V$. vinifera $\mathrm{x} V$. amurensis). The ancient cultivars 'Areni' from Armenia and 'Areni chernyi' from Germany matched except at VVMD32, where heterozygosity versus homozygosity was stated, most likely due to clone variation. 'Charentsi' from Armenia and 'Csarenci' from Germany were not identical but had high similarity and were placed in the same group of V. vinifera x V.amurensis cultivars). As it was expected, all investigated interspecific crosses were characterized by their high frost resistance, but differed by other phenotypic characteristics. This, however, was not enough for a clear distinction of the investigated genotypes, especially new bred varieties. Thus an application of modern techniques with a genetic approach was necessary for the determination of the genetic relation between the investigated genotypes.

\section{Conclusion}

Our comprehensive genetic research has shown high polymorphism and heterozygosity in Armenian grapevine cultivars of different origin. The Armenian genetic pool was formed during thousands years of folk selection and later was enriched by hybridizations and mutations.

The molecular characterization and analysis of the genetic structure in Armenian grape germplasm based on allele frequencies and heterozygosity contributes to the knowledge about levels and distribution of genetic diversity of the investigated cultivars. It reveals differences between aboriginal ancient and newly bred cultivars in the existing gene pool of Vitis.

By evaluation of the genetic relationship among the investigated cultivars a clear separation between the groups of ancient aboriginal cultivars, the Armenian new $V$. vinifera $\times V$. vinifera and $V$. vinifera $\times V$. amurensis crosses and seedless cultivars was detected. Very close relationships with high similarity were determined for five pairs of cultivars with the same pedigree or origin. However, two cases of possible homonymy were also detected. Our results reveal the high effectiveness of using SSR based genetic analysis of the grapevine germplasm and provide correct information about genetic diversity and genetic relations between accessions. 
All genetic profiles will be compared with allelic data from the Vitis International Variety Catalogue (www.vivc.de) and the European Vitis Database, (www.eu-vitis.de) [36]. The material of Armenian local cultivars significantly contributes to the understanding of the genetic variation in our grapevine collection and presents an important source for target selection. Special care should be taken to conserve these cultivars in ampelographic collections, because in some areas in Armenia the old vineyards are rapidly disappearing.

This research was partially supported by the DAAD (German Academic Exchange Service) Research visit grant (A/13/03780326) and the Research project of State committee of science at the Ministry of Education and Science of Armenia (15T-1E232).

\section{References}

[1] G. Melyan, S. Gasparyan, Caucasus and Northern Black Sea Region Ampelography (Vitis, Germany, 2012)

[2] P.E. McGovern, Ancient wine: the search of the origin of the viniculture. (Princeton University Press, New Jersey, 2003)

[3] F. Haroutunian, Reflections on the history of viticulture and winemaking in ancient and medieval Armenia. (Printinfo, Yerevan, 2005)

[4] R. Arroyo-García, L. Ruiz-García, L. Bolling, R. Ocete, M.A. López, C. Arnold, A. Ergul, G. Söylemezoğlu, H.I. Uzun, F. Cabello, J. Ibáñez, M.K. Aradhya, A. Atanassov, I. Atanassov, S. Balint, J.L. Cenis, L. Costantini, S. Goris-Lavets, M.S. Grando, B.Y. Klein, P.E. McGovern, D. Merdinoglu, I. Pejic, F. Pelsy, N.Primikirios, V. Risovannaya, K.A. Roubelakis-Angelakis, H. Snoussi, P. Sotiri, S. Tamhankar, P. This, L. Troshin, J.M. Malpica, F. Lefort, J.M. MartinezZapater, Mol. Ecol. 15, 8 (2006)

[5] H. Barnard, A. Dooley, G. Areshian, B. Gasparian, K. Faull, J Archaeol Sci 38, 8 (2010)

[6] J. Smith, O. Smith. Advances in agronomy 47, 56 (1992)

[7] R. Aroutiounian, A. Nebish, K. Margaryan, G. Melyan, Vitis 54, 4 (2015a)

[8] R. Aroutiounian, A. Nebish, G. Melyan, K. Margaryan, BIO Web of Conferences 5, 5 (2015b)

[9] M.R. Thomas, N.S. Scott, Theor. Appl. Genet. 86, 985-990 (1993)

[10] H. Lin, M.A. Walker, Am. J. Enol. Vitic 49, 5 (1998)

[11] J. Ibanez, M.T., De Andres, A. Molino, J. Borrego, Am. J. Enol. Vitic. 54, 9 (2003)

[12] E. Maletic, I. Pejic, J.K. Kontic, G.S. Dangl, A. Vokurka,T. Lacombe, N. Mirosevic, C.P. Meredith, Am. J. Enol. Vitic. 55, 7 (2004)

[13] R. Eibach, E. Zyprian, L. Welter, R. Töpfer, Vitis 46, 5 (2007)

[14] C. Bergamini, C., M.F. Cardone, A. Anaclerio, R. Perniola, A. Pichierri, R. Genghi, V. Alba, L.R. Forleo, A.R. Caputo, C. Montemurro, A. Blanco, D. Antonacci, Mol. Biotechnol. 54, 10 (2013)
[15] P. This, T. Lacombe, M.R. Thomas. Trends Genet. 22, 9 (2006)

[16] M.R. Thomas, N.S. Scott, Theor. Appl. Genet. 86, 6 (1993)

[17] J.E. Bowers, G.S. Dangl, R. Vignani, C.P. Meredith, Genome 39, 6 (1996)

[18] J.E. Bowers, G.S. Dangl, C.P. Meredith, Am. J. Enol. Viticult. 50, 8 (1999)

[19] K.M. Sefc, F. Regner, E. Turetschek, J. Glossl, H. Steinkellner, Genome 42, 7 (1999)

[20] D. Merdinoglu, G. Butterlin, L. Bevilacqua, V. Chiquet, A. Adam-Blondon, S. Decroocq, Mol. Breed. 15, 18 (2005)

[21] E. Zyprian, R. Topfer, National Center For Biotechnology Information NCBI, Genbank (Bethesda, Maryland, USA, 2005)

[22] G. Di Gaspero, E. Peterlunger, R.Testolin, K. Edwards, G. Cipriani, Theor. Appl. Genet. 101, 8 (2000)

[23] P. This, A. Jung, P. Boccacci, J. Borrego, R. Botta, L. Costantini, M. Crespan, G.S. Dangl, C. Eisenheld, F. Ferreira-Monteiro , S. Grando , J. Ibáñez, T. Lacombe, V. Laucou, R. Magalhães, C.P. Meredith, N. Milani, E. Peterlunger, F. Regner, L. Zulini, E. Maul,Theor. Appl. Genet. 109, 11 (2004)

[24] E. Maul, K.N. Sudharma, S. Kecke, G. Marx, C. Müller, L. Audeguin et al., Vitis 51, 7 (2012)

[25] V. Laucou, T. Lacombe, F. Dechesne, R. Siret, J.P. Bruno, M. Dessup, T. Dessup, P. Ortigosa, P. Parra, C. Roux, S. Santoni, D. Vares, J.P. Peros, J.M. Boursiquot, P.This, Theor. Appl. Genet. 122, 13 (2011)

[26] T. Lacombe, J.M. Boursiquot, V. Laucou, M. Di Vecchi-Staraz, J.P. Péros, P. This, Theor. Appl. Genet. 126, 14 (2013)

[27] S.T. Kalinowski, M.L. Taper, T.C. Marshall, Mol. Ecol. 16, 8 (2007)

[28] M. Nei, Analysis of gene diversity in subdivided populations. Proceedings of the National Academy of Sciences USA 70, 3 (1973)

[29] L. Excoffier, H.E.L. Lischer, Mol. Ecol. Res. 10, 8 (2010)

[30] F.J. Rohlf, NTSYS-PC numerical taxonomy and multivariate analysis system (Exeter Publishing, New York, NY, USA, 1988)

[31] M.C. Almadanim, M.M. Baleiras-Couto, H.S. Pereira, Carneiro L.C., P. Fevereiro, J.E. Eira-Dias, L. Moraiscecilio, W. Viegas, M.M. Veloso, Vitis 46, 4 (2007)

[32] W.F. Lamboy, C.G. Alpha, Journal of the American Society of Horticultural Science 123, 7 (1998)

[33] L.E. Martinez, P.F. Cavagnaro, R.W. Masuelli, M. Zuniga, Plant Science 170, 9 (2006)

[34] J. Martín, J. Borrego, F. Cabello, J. Ortiz, Genome 46, 9 (2003)

[35] P. C. de S. Leao, C.D. Cruz, S.Y.Motoike, Rev. Bras. Frutic. 35, 10 (2013)

[36] R. Töpfer, K.N. Sudharma, S. Kecke, G. Marx, R. Eibach, D. Maghradze, E. Maul, Bulletin de l'OIV, 11 (2009) 